\title{
European Officers and the Mainland Irregular Forces on the Ionian Islands, 1798-1814: A Comparison of Command and Tactics
}

\begin{abstract}
By Nicholas Pappas ${ }^{*}$
In the era of the Napoleonic wars, the Ionian Islands off the western coasts of Greece and southern Albania became a base of operations and an area of conflict in the Mediterranean in the years 1797-1814. In that period, Republican French, Russian, Imperial French, and British forces successively occupied these Greek-populated islands, formerly Venetian possessions. Each of these powers attempted to establish a nominally independent "Septinsular Republic" under their protectorate. There were efforts by all of these powers to organize native armed forces, some raised from among refugees from the mainland-bandits (klephtes), former Ottoman irregulars (armatoloi), and clansmen from the autonomous regions of Himara, Souli, and Mani. Although these refugee warriors were skilled in the use of weapons-flintlock firearms, sabres and yataghans-they fought and were organized according to traditions and methods that were different and considered "obsolete" in early nineteenth century Europe. This study will look into the organization, training and command of these troops by Russian, French, and British officers. It will study the successes and failures of these officers in forming these native warriors into regular or semi-regular forces. It will also examine how the attitudes and activities of these officers helped to develop the armed forces of the Greek War of Independence, 1821-1830.
\end{abstract}

Keywords: Napoleonic wars, Ionian Islands, armatoloi and klephtes, military forces

\section{Introduction}

In the generation prior to the Greek Revolution, upwards of four thousand mainland irregulars soldiered on the Ionian Islands. While many of these men were attracted to service by the pay, most were fugitives from Ottoman authorities in mainland Greek and Albanian areas, especially from Ali Pasha of Ioannina, and took on service to survive their exile. These refugees were already experienced in the use of arms. Some were wanted by Ottoman authorities for brigandage (the klephtes), while others had served as auxiliaries for Ottoman authorities (the armatoloi) and Christian notables (the kapoi of the Peloponnesus). Many of these exiles were members of autonomous warrior communities within the Ottoman Empire (the Himariotes, the Souliotes, and the Maniates). Men who had seen

\footnotetext{
*Professor, Department of History, Sam Houston State University, USA.
} 
previous service in the armies of Naples and Venice likewise played an important role in the forces organized on the Ionian Islands between 1798 and $1807^{1}$.

These troops armed themselves and fought in what contemporary observers knew as the Albanian manner, that is, in the mode prevalent among Muslim Albanians throughout the Near East. Their chief firearm was a long musket known as a toupheki or karyophyli. They also carried a set of pistols and a large sword, either a traditional long-knife known as a yataghan or a curved oriental sabre known as a pala. They trained and fought in a type of light infantry warfare that entailed swift movements, surprise attacks, sharpshooting and hand-to-hand fighting. Drilled movements and open engagements were not customary; ambushes and skirmishes were the rule. They often engaged in prolonged shooting matches with their opponents, taking advantage of the terrain for cover. Since musket fire was far from accurate, forays with pistols and swords were frequent. These troops, whether Muslim of Christian, Albanian, Greek or South Slavic, carried the same arms and fought in the same style (Pappas 1991, pp. 25-26). Small units of light infantry, such as jaegers, had seen increased service in the armies of European states in the $18^{\text {th }}$ century. In the early eighteenth century, the Habsburgs began deploying South Slavic grenzer troops from their military frontier to campaigns in the west. Other European powers responded by forming their own light infantry units. The British, for example, began recruiting Scottish highlanders as light infantry as well as organizing light infantry units in the American colonies (Rothenberg 1978, p. 20, Rothenberg 1966, pp. 18-21). Venice and Naples also formed light infantry units consisting of troops recruited from the Balkans. In the eighteenth century both Venice and Naples organized regiments from among Greeks and Orthodox Albanians, the Reggimento Real Macedone and the Battaglione dei Caccitori Albanese of the Kingdom of the Two Sicilies and the Reggimento Cimarrioto of the Serene Republic (Pappas 1981, pp. 35-59).

The armed forces on the Ionian Islands during the twilight years of the Venetian Republic prior to 1797 also included mainland irregulars. Aside from regular Venetian army units, Ionian Greek militia known as cernidi, the Venetians also employed companies of the Reggimento Cimarrioto and other GrecoAlbanian troops. On the eve of the first French occupation (1797-1799), the Venetian government hired more mainland Christian irregulars to offset weaknesses in the regular and reserve forces in its insular possessions. These forces included a battalion of Himariotes on Corfu, companies of armatoloi from Xeromero and Agrapha, and clansman from Souli, Lamari, Parga and Preveza (Grasset de Saint-Sauveur 1800, p. 109, Lungi 1856, pp. 253-254, Mertzios 1971, pp.310-313, Rodocanachi 1899, pp. 17, 103, Zotos-Molossos 1897, p. 67).

\footnotetext{
${ }^{1}$ On these military formations, see: Pappas (1991, pp. 21-59). Since the publication of my study there has been an interesting and profusely illustrated study by Leonidas Kallivretakis of the National Hellenic Research Foundation, entitled "Enopla Hellenika Somata ste dine ton Napoleonton Polemon (1798-1815)", a chapter in the Historia tou neou Hellenismou, volume 1- He Othomanike Kyriarchia, 1770-1821: Politike pragmatikoteta-organose kai thesmou ton hypodoulolon. Athens: Hellenika Grammata, 2003, pp. 185-200. Unfortunately, he seems neither to have known of my study nor to have cited it.
} 
In the wake of Napoleon's 1797 campaign in Italy and by the treaty of Campo Formio, the French occupied the Ionian Islands and fully integrated them into the Republic, administering them as three departments. In Napoleon's view, the Ionian Islands, in the hand of a strong military and naval power, could become a key to the conquest or to the support of the Ottoman Empire. Despite these strategic advantages, the French initially did not concentrate significant military and naval forces on the islands and the mainland appendages. Security and defence of the new possessions remained the duty of the small French and Italian landing forces and former Venetian troops who had entered French service. The French established a successor to the cernide militia known as the Gardes Nationales, and at the same time, they transformed old Venetian units into Companies Grecque Franche. Both formations attracted Ionian Greeks who had served in the regular Venetian army and the cernidi, as well as young men who were impressed by the ideas of the French Revolution. In addition to Ionian Islanders, a number of mainland armatoloi and other irregulars employed by the Venetians before the French occupation took service with the French (Pappas 1991, pp. 97-98).

Within two years of their occupation, a combined Russo-Turkish naval expedition expelled the French from the islands by as part of the second coalition against France ${ }^{2}$. After consolidating their occupation, the Russian and Turkish fleets left the Ionian Islands to engage the French off the Italian Coast and in the western Mediterranean. At the same time, the Russian-sponsored government of the islands, known as the Septinsular Republic, undertook to build a local military force, the so-called Septinsular army. A lack of funds and a dearth of recruits made it difficult to build an effective armed force. Soon after the fledgling army's inception, the new republic broke apart with civil strife on most of the islands. The Septinsular army could neither control nor remain aloof from the uprisings and secessionist movements that arose on the various islands. The disparate nature of the army's components facilitated the politicization of the armed forces during the period of disturbances in 1799-1800, which included officers and men who had served under different regimes-Venetian, French and Russian. In addition, since the local governments paid the provisional armed forces on outlying islands, the troops were prone to follow the lead of their immediate employers (Pappas 1991, 122-132).

\section{Russian Forces}

Between 1799 and 1802, Russian forces intervened both officially and unofficially on two occasions to bring order to the islands. In the summer and fall of 1802, Russian naval and land forces, 2 frigates and 600 infantrymen, brought about a permanent restoration of order. Aiding these limited Russian forces were the few loyal Septinsular troops on Corfu and by mainland irregulars, many of whom had served in the Russian Turkish naval expedition of 1798-1799 and had later functioned as auxiliaries on the islands in the intervening three years. During

\footnotetext{
${ }^{2}$ On the expedition, see Tarle (1959).
} 
this period of troubles, the Greco-Albanian troops had been a neutral yet stabilizing factor. The soldiers of the mainland units took no sides in the internal conflicts and merely served the governments that employed them. Upon the return of Russian forces, these troops joined in the pacification of the unruly islands. The mainland units, known under several appellations, became such a vital part of the military of the Ionian Islands that they comprised about one/half of the permanent infantry forces of the Septinsular Republic. Between 1799 and 1803, the number of mainland irregulars rose on the Ionian Islands from 300 to 700 troops (Pappas 1991, 137-150).

In the face of perceived or real threats of a French military expansion in Italy, Russian forces reappeared in the Mediterranean in a major way between 1803 and 1805. The government of Alexander I followed closely the advance of the French Army toward southern Italy and the activities of French agents in the Balkans and saw them as threats to the Septinsular Republic and the Ottoman Empire. The Russian strategists felt that the small Russian forces on the Ionian Islands were inadequate to meet any French challenge. Moving toward an alliance with the England in 1804, the Russians began expansion of their armed forces on the islands. In late 1803, Russian forces in the Septinsular Republic and its waters amounted to 1,200 troops and 2 warships. By the end of 1805, these forces grew to over 12,000 men and 39 naval vessels. These land and naval units transferred to the islands via the Turkish straits by treaty with the Ottoman Empire (Pappas 1991, 152-154).

Aside from building their own military on the Ionian Islands, the Russians attempted to increase the number of native forces allied to them in the area. In 1803, the Russian Plenipotentiary, Georgios Mocenigos, tried to induce the Septinsular Republic to increase its army to 2,000 men and its navy to 14 vessels. In 1804, the Septinsular Republic gave command of its regular forces to Colonel Emmanouel Papadopoulos, a Russian officer of Greek origin who had arrived at the head of the first Russian reinforcements in March of that year. Colonel Papadopoulos and many of the Russian officers involved in the organization and training of the Septinsular Republic and the mainland troops were products of Greco-Russian military ties going back over thirty years (Pappas 1991, 158-162).

Greeks, Albanians and other Balkan peoples began entering Russian military and naval service in large numbers because of their participation in the RussoTurkish Wars of 1769-1774 and 1787-1791. Their recruitment followed the same pattern in both conflicts. They first became involved in insurrections in their homelands instigated by Russian agents, often of Greek origin, who emphasized common religious and cultural ties. When these uprisings failed, fugitives from these abortive movements took on service as auxiliary marines and sailors in the regular or privateer naval forces of Russia operating in the Mediterranean. With the coming of peace in both wars, many of these marines and sailors immigrated to Russia's newly annexed territories along the Black Sea. There they either joined regular forces or formed military colonies in the Crimea and Odessa. Light Infantry units (Grecheskii Polk, Balaklavskii Grecheskii Pekhotnyi Battalion, and Odesskii Grecheskii Divizion) units were organized from these colonies and served 
as territorial guards in peacetime and as marines in wartime (Pappas 1991, 61$94)^{3}$.

Besides these formations, Russia established a school and later a cadet corps for the training of regular officers from among Greek and other foreign Orthodox refugee youths. This school, known as the Kadetskii Korpus chuzhestrannykh edinovertsev (Cadet Corps of Foreign Coreligionists), was founded originally in 1774 as a gymnasium for refugee Greek boys of the Russo-Turkish War. In April 1775 , the School became a cadet corps and its name changed to reflect the addition of students of Bulgarian, Serbian, Arab and other backgrounds. The cadets were educated for future training and commissioned service in army and naval forces. The curriculum included instruction in French, German, Greek, Italian, Russian and Turkish, as well as arithmetic, geometry, geography, drafting and dance for the lower grades. Upon completion of these general courses, cadets were obliged to continue training for their branches of service. The School started with a complement of 46 cadets and later maintained a student body of about one hundred cadets. Although the student body was composed of boys of various origins, most Russian sources indicate that a majority of the corps' graduates were Greeks. During the twenty-three years of its existence, the school produced hundreds of graduates, most of whom served as army and navy officers. In addition to military activities, some of the corps graduates took on diplomatic, consular and intelligence duties, serving in embassies and consulates in the Near East and the Mediterranean. Many of the Russian organizers and trainers of the regular Ionian and irregular mainland units came from this cadet corps and the other institutions mentioned above, including Colonel Papadopoulos (Beskrovnyi 1958, p. 452, Korguev 1897, pp. 155-164, Korguev 1913, pp. 197-198).

Papadopoulos immigrated to Russia as a youth following the Russo Turkish War of 1769-1774. He attended the Greek Gymnasium and the Cadet Corps of Foreign Co-religionists, commissioned an officer of engineers in 1781. He later transferred to the infantry, in which he distinguished himself at the siege of Ochakov against the Turks in 1788. He then joined the general staff and served as a liaison officer in the Russian embassy in Constantinople in 1793-1794. Later he commanded the Ladozhskii Musketeer Regiment until 1803, in which he organized a garrison battalion and artillery command at Kamenets for eventual duty on the Ionian Islands ("Emmanuil Grigor'evich Papandopulo" 1846, pp. 287288, Klochakev 1902, p. 302, Zerlentes 1887, pp. 201-207).

In his role as commander of the Septinsular army, he restructured the regulars and based their organization on a Russian model. He composed a military manual that revised regulations and practices away from the Venetian model. This manual, written in Greek, appeared with a parallel Italian translation by order of the Septinsular government in 1804. In the next year, Papadopoulos also took command of the mainland Greek forces in Russian service, attaining the rank of Major General (Papadopoulos 1805a).

Since the finances and eligible manpower of the Island Republic could not sustain a larger armed force, Russian authorities planned and worked in 1804 for

${ }^{3}$ Works appearing on Greek units in Russia since the appearance of my study include Avgitidis (1993). 
the formation of a large corps of Greco-Albanian troops similar to the forces they had developed in the Russo-Turkish war of 1769-1774. Toward this end and toward countering French activities, the Russians established new consulates on the mainland (at Arta, Preveza and Patras), employed recruiting agents, and reestablished ties with armatoloi, klephtes, kapoi and clansmen of Souli, Mani and Himara. The impetus for entry of these martial elements into Russian service was not only propaganda and active recruitment, but also the growth and intensification of the refugee problem on the Ionian Islands (Pappas 1991, pp. 162-176).

\section{Legion of Light Riflemen}

The first refugees organized into Russian service were the Souliotes, who settled on Corfu after the fall of their homeland and the failure of their aborted attempt to resume war against Ali Pasha with Russian aid in June 1804. After an exhaustive war with Ali Pasha and the loss of their homeland, the remnants of the Souliote people sought asylum at Parga and then on Corfu, where most ablebodied men entered Russian service. They formed a unit known as the Souliote Legion, numbering to about 600 troops by March 1805 . They would eventually number over 1,300 by the end of 1805 and formed into two sections of the new Russian sponsored unit. Known as the Legion of Light Riflemen or hunters (Legion Legkikh Strelkov in Russian, Legion Elaphron Kynegon in Greek) (Pappas 1991, pp. 180-191) ${ }^{4}$. The Russians also organized a third section on Corfu, composed of Himariotes. Having likewise suffered at the hands of Ali Pasha and his lieutenants, the Himariotes cemented relations with Russian authorities on Corfu to assure their autonomy in the wake of the fall of Souli. These troops, many with experience in the Venetian Reggimento Cimarrioto or the Neapolitan Reggimento Real Macedone, immediately mustered on Corfu in a section of about 400 men known as the Himariote Legion by mid-1805 (Pappas 1991, pp. 191195). One the island of Cephalonia, the Russians recruited Souliotes, as well as refugee klephtes and Armatoloi, into the Epirote legion, consisting of two sections. They also organized a section on Zakynthos from among Morean fugitive kapoi and klephtes called the Peloponnesian Legion. The Russians formed a second section on Zakynthos, made up of Maniates, known as the Spartan Legion, although it was not originally part of the planned Legion of Light Riflemen. The sections neither on Cephalonia, nor on Zakynthos reached full compliments until later in 1806 (Pappas 1991, pp. 195-211).

The growth of the Legion of Light Riflemen, as seen above, varied from section to section. In May 1805, Russian authorities projected that the larger Legion of Light Riflemen would have an overall strength of 2,080 officers and men. By the end of 1805, the number of troops in the Legion amounted to 1964 men, of which 1,354 were Souliotes, Roumeliotes and Epirotes, 359 were Himariotes, and 251 were Peloponnesians and Maniates. The Legion eventually

\footnotetext{
${ }^{4}$ Since the appearance of my study, a very thorough investigation of the Souliotes as appeared as a dissertation and subsequently as a book in two editions. This work is Psimouli (1995, 1998, 2005).
} 
reached the height of its manpower in 1807 with 2,340 legionnaires in service (Pappas 1991, pp. 213-214).

The first sections organized on Corfu initially had regular Russian officers, mostly of Greek origin, as section commanders and adjutants. Native leaders with brevet commissions commanded the sections on Cephalonia and Zakynthos. These section leaders were responsible to the Russian commanders of their respective island garrison as well as to the commander of the Legion, Major General Papadopoulos.

The initial commander of the Corfu units was Colonel Alexander Benkendorf, an aide-de-camp of the Tsar who arrived on Corfu in September 1803. Under Benkendorf, the Souliote companies rose in strength to about 600 men and collectively named the Souliote Legion. Colonel Benkendorf developed a good rapport with the Souliotes, as is evidenced by the testimony of Christophoros Perraivos (Perraivos 1815):

... appointed commander over all of them was an affable young man by the name of Benkendorf, of Russian race, who admired them greatly and treated them with sincerity. He often arranged mock battles and war games, defraying the expenses in most cases from his own resources. He remained their commander but a few months and later left for Russia.

Benkendorf remained in overall command of both the Souliote companies and the four Himariote companies. Russian sources also indicate that he played an important role in the initial organization of these units on Corfu. He held command of the Souliote Legion until March 1805, when he was recalled to Russia. Benkendorf's cursus publicus culminated with his serving Tsar Nicholas I as commander of his political police, the Third Section, and as one of his principal advisors between 1825 and 1844 (Stanislavskaja 1976) ${ }^{5}$.

In the over 20 years since my initial study, I often wondered Benkendorf, the head of notorious secret police had any influence in the more active role of Russia in the Greek revolution under Nicholas I. Benkendorf's recently published memoirs indicate that he had nostalgia for his old command in Corfu, although he probably could not reveal it because of his position in the years 1826 to 1847 . In his memoirs, he wrote ${ }^{6}$ :

These brave Souliotes, whose antique costume resembles that of the ancient Spartans, told me that one day they would express their devotion to me had by raising me with their own hands on the walls of Constantinople. The Greek still remains what he was in the heydays of Athens, mere word inspires him; and the enthusiasm to which he is

\footnotetext{
${ }^{5}$ Bogoliubov to Kurakin (7 March 1805) in Pis'ma V. F. Bogoliubova, p. 237; "Graf Aleksander Khristoforovich Benkendorf", pp. 695-698.

${ }^{6}$ Mémoires du comte Alexandre Benkendorf Général cavalerie, Aide de Camp Général de S.M.E. l'Empereur de Russie. PN Griunberg (ed.). Moscow: Iazyky skavianskoi kultury, 2001. From the Russian translation Aleksandr Khristoforovich Benkendorf, Vospominaniiia, 1802-1837. OV Marinina (tr.). Moscow: Rossiiskii Fond Kul'tury, 2012, pp. 106, 111. Benkendorf's memoires reads like a picaresque novel, at least in the Corfiote section, in which he moves from one romantic conquest to another. It reads much like Casanova's reminiscences of his encounters with the Reggimento Cimarrioto in Venice. See Casanova (1924, pp. 133-135).
} 
most susceptible than all the nations of Europe, is to exalt to the highest level of power, he who will be able to fire this enthusiasm and return this nation to its former independence.

Upon reaching St. Petersburg and meeting with the Tsar to report on Corfu, Benkendorf told the Tsar that he wanted return to Corfu and his Souliote legion, but was denied his wish by the Tsar. While Benkendorf's philhellenism became stifled by his duty to the Tsar, it seems that a member of his family held philhellenic views and acted upon them. Scholars have discovered that Benkendorf's sister, Darya (Dorothea) Lieven, wife of the Russian ambassador to London, used her social contacts and feminine wiles as an agent for Greek independence, serving both the Tsar and the Greek cause, whole consorting with such opponents of Greek Independence as Klemens Von Metternich and Richard Castlereagh. Some of these scholars believe that she was influential in the formation of English-French-Russian detente, which aided in Greek independence by its intervention at Navarino on 1827 (St. Claire 1972, pp. 314-315) ${ }^{7}$.

With Benkendorf's departure, Emmanouel Papadopoulos assumed command of all sections of the legion and continued its formation on solid foundations, developing a general organization and conditions of service. He did so by formulating a convention of service for the troops of the legion for General D'Anrep in May 1805 (Convention of the Epeirotosouliotes and Peloponnesians with General D'Anrep 1805, Goudas 1876, pp. 254-255).

The convention's conditions of service were similar yet in some ways different from those of the irregular units in Septinsular service. Pay for the officers and men of the Legion was the same as that of the Septinsular Macedonian Corps, that is 60 grosia per month for captains, 40 grosia for lieutenants, 25 grosia for sergeants and musicians, and 18 grosia, 30 para for soldiers. They, like the albanesi in Septinsular service, supplied their own arms and attire "according to the customs of their nation" (Convention of the Epeirotosouliotes and Peloponnesians with General D'Anrep 1805) ${ }^{8}$.

Differing from the mainland troops of the Septinsular Republic, the legionnaires were obliged to campaign outside of the Ionian Islands. According to their oath of entry (Convention of the Epeirotosouliotes and Peloponnesians with General D'Anrep 1805):

We the Epiroto-Souliotes and Peloponnesians and Himarriotes, promise by oath that we shall serve our most powerful emperor faithfully and shall go against any enemy which the commanding general of Imperial forces orders us to ... vowing to protect, on the part of us all, the good order and discipline with faithful service, zeal, and

\footnotetext{
${ }^{7}$ Journalist/Historian Panagiotes Paspaliares, has asserted that she was a double agent for Capodistria, see "Diarroe sto "agio diskopoterio" tes Ieres Symmachias", (Greek) at CapodistriaSpinelli-Europe (April 2012) http://main.cse-initiative.eu/?cat=20 and "Greece's Secret Spy in Metternich's Bedroom", (English) at Capodistria-Spinelli-Europe (April 2012)- http://cseinitiative.eu/spip.php?article49.

${ }^{8}$ A grosi was an Ottoman piastre or kuruş. The smaller denomination was the para, forty of which made one grosi.
} 
courage, having the certain hope that we shall receive our allotted pay and board, without any difficulty and shortcoming from any quarter.

Regulations for leave and discharge from the Legion were liberal and generous. When not on campaign, legionnaires could take leaves of up to two months with pay for settling personal affairs. Furthermore, legionnaires could receive $\cdot$ a discharge from service upon giving three months' notice to their captain to give time to find suitable replacements. If legionnaires received disabling wounds while in service, they would receive a discharge and a pension of half pay as compensation. Upon conclusion of hostilities and if the Legion of Light Riflemen was no longer needed for imperial service, its complement would be discharged and returned to their areas at Imperial expense. Even though the men of the Legion were irregulars, this condition of service seems unusual, since many of the legionnaires could not return to their homelands, being refugees. The future of the troops of the Legion of Light Riflemen after Russian service was to be a problem after the treaty of Tilsit in 1807 (Convention of the Epeirotosouliotes and Peloponnesians with General D'Anrep 1805).

In spite of the fact that the ranks of the Legion came from different areas, entered Russian service under different circumstances, and garrisoned different islands, they nonetheless came under a single command with the same conditions of service. Major General Papadopoulos maintained correspondence and met periodically with section commanders and other officers of the Legion. Papadopoulos also composed a military manual in Greek, which he printed and distributed for the use of the officers and sergeants of the Legion; and dispatched least 20 copies of the manual to each section by August 1805. The manual defined the organization of the Legion and the obligations and duties of every rank of the corps. Thus, Papadopoulos provided the military manuals for both the regular Septinsular army and the Legion of Light Riflemen, and followed in the footsteps of Georgios Papazoles, the Russian military agent who composed the first Modern Greek military manual prior to the Russo-Turkish war of 1769-1774. Papadopoulos' manual for the Legion of Light Riflemen was an original composition rather than a translation or paraphrase of existing Russian manuals ${ }^{9}$. It took into account both the origins of its members and the different military ethos. In the Manual, he attempted to cement the disparate elements of the legion by emphasizing Greek national consciousness (Rados 1916, p. 50, Jochalas 1975, pp. 18-19, 21-22, 7274, Kasomoules 1939, p. 2, Kolokotrones 1971, p. 58) ${ }^{10}$ :

Remember and engrave in your hearts that you are the descendents of the renowned Greeks, of the most martial and most tactical Pyrrhus, and of the most brave and courageous Skenderbeg of more recent times. You have the bravery of your

\footnotetext{
${ }^{9}$ Papadopoulos (1805b) as quoted in Rados (1916, p. 48). This very rare book has remained unavailable to this writer. However, Rados, above, quotes it extensively. Papazoles' manual is available in PDF form from the University of Crete, I used a copy of Papadopoulos' Septinsular manual at the National Library of Athens. This author hopes that the legion's manual will be similarly available. Pappas (1991, p. 103, n. 21, 545).

${ }^{10}$ Greeks of that time, as well as Orthodox Albanians, considered the Albanian national hero to be their own.
} 
ancestors. You need only to have concord among yourselves; love, fraternity, obedience to commanders, good military order, eagerness and zeal, and surely you will glorify the Greek name.

Each section or legion consisted of four hekatonarchies (centuries or companies). In 1805, each company was to have a complement of one hekatonarchos (sotnik, centurion or captain), two pentekontarchoi (piatdesidtniki or lieutenants), ten dekarchoi (desiatniki or sergeants) and ninety stratiotes (riadovi or privates), amounting to 103 officers and men. Later, each company also had an ensign or standard-bearer (semaiophoros or znamenik). Outside the complements of the companies, each section had a commander (chastnyl nachal'nik) with the rank of major (maior, maggioros or taxiarchos), as well as an adjutant and four musicians. The Legion also had Greek Orthodox chaplains, either serving in the ranks or holding chaplain's rank (Convention of the Epeirotosouliotes and Peloponnesians with General D'Anrep 1805, Pappas 1991, pp. 212-213).

The manual called for each section to have its own standard. The basic emblem for all the sections' standards was the double-headed eagle with laurel branches and a crown. Each standard also had the saying "God is with us" and "Know, ye nations and submit" on opposite sides of the flag. The first and second Souliote sections had standards with white and blue fields respectively, while the third and fourth Epirote sections had ones with red and yellow fields. The fifth Himariote section's. standard was orange, while that of the sixth Peloponnesian section was a checked white. The colour of the Spartan Legion's flag is unknown (Rados 1916, p. 47).

Although the basic units for recruitment and organization for the Legion were the companies and the battalion-sized sections, the basic unit for drill training and combat was the squad of ten men known as the dekarchia. The dekarchoi (desiadtniki), commander of the squad, was the equivilant of a sergeant. For example, for the duties of enlisted men in preparing for action, Papadopoulos wrote (Rados 1916, p. 48):

At the command of the sergeant, he [the soldier] musters at the place designated; when the sergeant gives the signal, the soldiers will disperse and will take their covered positions ... All these movements must be done by the soldiers without shouts or disturbances and they must show every obedience to the commands of the sergeant.

The emphasis on small unit actions in the Legion manual resembled the tactics of modern armies, rather than those of the eighteenth century. The manual also conformed to the type of combat familiar to the men of the Legion, as Papadopoulos noted (Rados 1916, pp. 47-48):

Observing the natural ways and habits of the Epiroto-Souliotes, Cheimarriotes and Peloponnesians, who always fought with a simple, natural order, with little need for drill, since they are aided greatly by nature and covered positions, it is difficult and unbeneficial to have them drill in the order of European forces, and for this they are 
designated semi-regulars (aploutaktikoi) and will be called light hunters (elaphron kinegon).

For the most part, the Legion of Light Riflemen performed well, both in the Russian offensive operations in the Mediterranean, as well as in the defence of the Ionian Islands. These campaigns began with the Anglo-Russian expedition to Naples in the fall and winter of 1805-1806. The whole complement of the Legion, as part of a Russian contingent of over 11,000 men, landed to Italy in the occupation and defence of the Kingdom of the Two Sicilies, against the French. Within two months, however, Napoleon's victory at Austerlitz and the vacillation of Neapolitan court made the expedition's position untenable. The British and Russian corps were obliged to withdraw, the former to Sicily and the latter to the Ionian Islands (Pappas 1991, pp. 221-225). Nevertheless, some of the legionnaires made an impression on a British officer (Bunbury 1854, p. 219):

Their very gait told their tale: it was the noiseless creeping of a cat in search of prey: their long steps gave forth no sound; their eyes, though lighted by no passion, were incessantly moving, and marking all things before and behind and on every side. A sort of coarse shirt belted around their waist, with a capote of the skins of sheep or goats formed their dress: and a long gun and a stout knife their arms. They could have done very little harm to the French, but they would have been deadly protectors to the Italians.

The Legion of Light Riflemen suffered mostly from malaria on campaign in Italy, which plagued the unit for months. For the duration of 1806, most of the troops remained garrisoned on the Ionian Islands, although some claim that elements of the Legion served with Russian naval forces in southern Dalmatia in the summer and autumn 1806 (Pappas 1991, pp. 225-238).

The outbreak of a new Russo-Turkish war in late 1806 brought about new duties for the Legion and related units. Two hundred sixty legionnaires served as marines with Admiral Seniavin's naval force in the northern Aegean in 1807. In this capacity, they participated in the capture and later defence of the island of Tenedos near the Dardanelles (Pappas 1991, pp. 225-238).

The rest of the legion, together with the Septinsular Macedonian Corps, the newly formed Special Greek Corps, and other levies of refugee klephtes and armatoloi, played an important part in the defence of the Ionian Islands, especially Lefkas. In the spring and summer of 1807, the forces of Ali Pasha of Ioannina, abetted by French advisors, attempted to capture Lefkas from the adjacent mainland. A mixed force of Russian regulars, Septinsular militia and continental auxiliaries successfully defended the island, together with the town of Parga, from the assaults of Ali's troops. Besides these defensive measures, mainland irregulars served in offensive operations against the Ottomans on land and at sea. They made forays on the mainland and privateer raids, amounting to insurrectionary movements, led by chieftains bearing Russian or Septinsular brevet commissions (Pappas 1991, pp. 238-245). These movements, sponsored by the Russians, were 
active as far afield Macedonia, Thessaly and the northern Aegean Island, including the activities of Nikotsaras, Papathymios Vlachavas (Pappas 1991, pp. 246-253) ${ }^{11}$.

With the cession of the Ionian Islands to France because of the Treaty of Tilsit in the summer of 1807, Russia was obliged to withdraw its forces from the islands and the Mediterranean. In spite of this withdrawal and the temporary RussoTurkish armistice of Slobozia, aftershocks of the hostilities continued in Greek Lands. For example, the rebellion of Efthymios Vlachavas broke out in early 1808, after the French had taken possession of the Ionian Islands. Similarly, the privateer activity in the Aegean by Macedonian, Thessalian and other corsairs continued into 1812, four years after the withdrawal of the Russian fleet. Unlike previous Russian engagements and withdrawals from the Mediterranean, such as during the Russo-Turkish wars of the late eighteenth century, those native troops who had served with the Russians did not have the option of resettling in Russia. Instead, the men of the Legion of Light Riflemen and related units took the opportunity to transfer to French service, which they did with the proviso that they would never fight against Russia. These troops did not leave with the Russian forces since there was no danger of Turkish reprisals against them, since the French were neutral over the Russo-Turkish war. Russia was not able to resettle them in Russia, since they were still at war with the Ottomans and could pass through the straits to the Black Sea. Furthermore, there had been changes in the Russian policy on foreign settlers in Russia, which mitigated against the formation of another Greek military colony in the Russian Empire. Thus, the formations of refugee warriors founded under Russian tutelage were to continue under new patrons (Boppe 1914, pp. 221223, Boppe 1901, pp. 161-162).

\section{French Regiment}

After the Russian withdrawal from the Ionian Islands, the troops of the Legion of Light Riflemen and various other military formations in which Greeks served transferred to French service. After an abortive attempt to integrate each company of the former legion into a regular French battalion, the French organized the troops of the auxiliary units that had served the Russians into Le Regiment Albanaise (the Albanian Regiment) and Les Chasseurs a Pied Grecques (The Greek Infantry Skirmishers). The former unit had a strength of over 2,000 men, while the latter amounted to nearly 1,000 troops. Eventually the Greek Skirmishers merged with the Albanian Regiment, forming a single Albanian Regiment of over 3,000 men, organized into six battalions of six companies each. This structure resembled that of the Russian Legion of Light Riflemen in 1805, with the difference that each battalion had six companies, rather than the four in each section of the Legion (Pappas 1991, pp. 261-266).

\footnotetext{
${ }^{11}$ These and other operations included shore attacks and raids on Ottoman shipping and by Hydriotes, Ionians, Macedonians, Maniates, Peloponnesians, Thessalians, and others who either bore letters of Marque or held brevet commissions from the Russian and Septinsular governments, including officers in the Legion of Light Riflemen.
} 
Unlike the Legion of Light Riflemen, the Albanian Regiment for the most part did not operate as an auxiliary force in campaigns, but rather served as a garrison unit. With the exception of Corfu, a minimum of regular French troops deployed on outlying islands. Instead, chiefly mainland irregulars, Italian regulars and local militia garrisoned the islands. By confining the irregulars of the Albanian regiment to garrison duty, the French overlooked their main asset as skirmishers, and brought out their weaknesses as regular troops (Pappas 1991, pp. 266-268). The French had difficulty submitting the mainlanders to fortress duty and settling the disputes among the officers and men of the Albanian Regiment. One factor in these problems was that the French did not employ regular officers of Greek origin in command positions in the Albanian Regiment to the extent that the Russians employed them in the Legion of Light Riflemen. Initially they tried to "regularize" the mainlanders, them with little success. They also promoted to native commander a man who had ritually repudiated the Tsar by stepping on a Russian metal he had earlier received. The troops nearly mutinied because they considered his action babesiko or atimo, that is, perfidious. The bulk of the officers and men of the former legion, because of their patriarchal code of personal honour (philotimo in Greek, besa in Albanian), took their oaths of allegiance to the Tsar seriously. When the French command ordered the troops of the Legion and Corps to take an oath of allegiance, they refused to accept an oath that would call on them to act against Russia. Despite threats, they swore only that they would fight all of the French Empire's present and potential enemies with the exception of Russia (Boppe 1901, pp. 163-164, Pappas 1991, pp. 262-264) ${ }^{12}$.

The French commander of the Regiment, Colonel Minot tried assiduously to organize and lead his charges, but ended up despising his regiment, in 1812 he wrote (Boppe 1914, pp. 256, 261, Boppe 1901, pp. 207, 210):

I have languished on Corfu for nearly five years. . . .Up to now I have commanded the Albanians with resignation, though this was the most distasteful command a colonel could have.

Minot by then wanted to command a regular French regiment and seemed to have been frustrated in his attempts to mould his disagreeable charges into the image he preferred. For example in one order, he confined soldiers to the barracks and allowed leave to only those with large families. He forbade the troops to bear arms outside their compounds and posted guards to enforce this. Minot took measures to ensure the total mustering of companies for inspections. So much emphasis did he place on this, in fact, that he even jailed one captain, Markos Botsares, for eight days for having displayed "sloth" in the mustering of his men. This penchant for discipline contrasted with the concept of restrained discipline practiced by General Papadopoulos in the Legion of Light Riflemen (Boppe 1914, pp. 256, 261, Boppe 1901, pp. 207, 210, Pappas 1991, pp. 276-277).

The French could have minimized the problems of they allowed Greek officers from their regular forces, such as Colonel Nikolaos Papazoglu-Tsesmeles, to serve as commanders and advisors for the irregular units, as, in fact, the Russians had

\footnotetext{
${ }^{12}$ Proclamation to the Albanians, 14 October 1807, in Boppe (1914, pp. 224-225).
} 
done. Familiar with the European forms of military discipline as well as the language and customs of their charges, Greek officers would have been better able to negotiate such minor crises and prevent them from becoming major problems. Unfortunately, the pool of regular Greek officers available to the French was smaller than that of the Russians, which had grown as due to the ties and institutions dating back to the Russo-Turkish wars of the eighteenth century (Pappas 1991, pp. 270-271).

\section{British Regiment}

The development of the Albanian Regiment became further impaired by the British seizure of Cephalonia, Cerigo (Kythera), Ithaca and Zakynthos in the fall of 1809 , within two years of the French occupation. Most of the captured troops of the Albanian Regiment garrisoned on these islands soon entered British service and began serving into a rival unit, the Greek Light Infantry Corps. This Englishsponsored formation rose to a numerical strength of 500 men by early 1810 and participated in the capture of Lefkas in March of that year. By 1813, the Greek Light Infantry Corps, officially named the Duke of York's Greek Light Infantry Regiment, amounted to over 800 officers and men. While this regiment was serving in Sicily in 1813 and 1814, the British raised a second regiment on the Ionian Islands. This new unit reached a complement of 600 troops in late 1813 and was commissioned the Second (or the Duke of York's) Greek Light Infantry Regiment. Elements of this second regiment took part in the capture of Paxos and Parga in 1814 (Pappas 1991, pp. 279-291).

The rise of the British-sponsored regiments saw a corresponding decline in the manpower and activity of the French-sponsored Albanian Regiment. Each success in Britain's island-hopping campaign brought a loss in the number of troops in the Albanian Regiment and a concomitant rise in the number of troops of the Greek Light Infantry Regiments. By 1814, the Albanian Regiment was limited to about 1,500 officers and men, 1,200 on Corfu and about 300 on Paxos and in Parga. Disappointed by the performance of the Regiment's components against the British on the other islands, Minot and other French officers wished to deactivate the remnants of the unit. General Donzelot, the commander of French forces on Corfu, nevertheless maintained the Regiment intact until the surrender of Corfu in May 1814 (Pappas 1991, p. 278).

The situation of those Greeks who served in the British forces presents a different picture from that of the French sponsored troops. The initial $\cdot$ English commander, Richard Church, recognized their martial qualities and the benefit of doing further recruitment. He went so far as to return to England in 1812 to petition for the organization of a second Greek regiment. The native officers likewise had great respect for him. In a memorandum that they gave to him upon his departure for England, they said (Boppe 1914, pp. 259-264, Boppe 1901, pp. 209-213):

...we cannot do otherwise than testify publicly that you are the cause and the promoter of such merits, as we possess at present and that you have nobly 
demonstrated the error of those European nations whose rooted prejudices will not allow them to believe that modern Greeks are amenable to discipline and instruction...

Church even bore with him to England another letter by the men under his command asking for aid in freeing their land, which he supported. His good reputation among Greeks was such that even those who served in the rival French unit thought highly of him, as attested by Christophoros Perraivos, who commented that, "I became acquainted with the man only for a few hours, but his fame had preceded him sometime before my small experience; when I conversed with him. I could see the qualities of an Epaminondas, a Themistocles, reigning in him" $^{13}$. In comparing Colonels Minot and Church, Perraivos (1815, pp. 81-81, 85 wrote:

At the head of the Greek Corps was the aforementioned Colonel Minot. He used the Corps more for his own gain, and not toward glory and justice. He recognized no distinction between officer and soldier. Good and bad were the same to him and it can truly be said that virtue went unrewarded and vice went unpunished. He was skilful to the extreme at hiding his internal and external feelings about the men, and, in order to have his schemes secured, he promoted many from the Corps to ranks that they did not merit at all, made by the exchange of silver. ...As unlucky as we were under the command of Colonel Minot, the ones who served under a Colonel by the name of Richard Church were most fortunate.

Another factor for the success of the British in their organization and command of the Greek Light Infantry Regiments was that Church and his fellow officers spoke Greek. According to a report of Ioannes Kapodistrias, then in the Russian Foreign Service $^{14}$ :

The English in most recent times have with them some regiments in their service. They have been organized on Zante (Zakynthos) and Cephalonia. The captains and majors in them are Greeks, while the highest-ranking officers are English who are dressed in Greek costume and speak perfect Greek. A number are found in French service on the island of Corfu and are limited to four companies. This is the remnant of those, who in their time, were in Russian service.

One can attribute the relative success of the British in employing to the enthusiasm and organizational skills of Major, later Colonel, Richard Church. He had acquired a reputation as an expert trainer and commander of foreign troops. In 1805 , he had made a study of the military employment of Calabrian brigands in southern Italy, and from 1806 to 1808, he had commanded a unit of Corsican Rangers, Napoleon's own compatriots, on reconnaissance missions in Frenchoccupied Italy (Lane-Poole 1890, pp. 3-21). While serving as quartermaster

\footnotetext{
${ }^{13}$ Captains Kolokotrones, Stratos, Vlacbopoulos, Vilaetes et al. to R. Church, 24 July 1812, as quoted in Dakin (1955, p. 16).

${ }^{14}$ I Kapodistrias to Count Stackelberg, Note on the present state of the Greeks, 25 November 1811. French original published in Arsh (1976, p. 266); Russian translation in Arsh (1972, pp. 374-375).
} 
general on the British expedition against the islands in October 1809, he had encountered the troops of the Albanian Regiment and had proposed to the expedition's commander, Brigadier General James Oswald, that they recruit the Greco-Albanian troops. Oswald gave him his unqualified support. On Church's enthusiasm, Brigadier Oswald reportedly said (Lane-Poole 1890, pp. 27-28):

The first embodiment of the Greeks in our service was one of those delicate experiments demanding a rare and unusual combination of conciliation and firmness, and indeed of that enthusiasm by which great difficulties alone can be overcome. No one was so capable of embodying and disciplining people whose love and respect you had by the most valid titles acquired....For my own part, I am convinced that our corps is but the commencement of a great plan for engaging numbers of Greeks in our service.

General Oswald displays another reason behind the British success. He was a Scot educated at a French military academy before the Revolution. He served as an officer in the West Indies, Netherlands, Egypt, Sicily, and Calabria. Being Scottish, Oswald probably had experience with highlanders, as well as an appreciation of efforts to train warriors into soldiers. Like the Russian commander, Emmanouel Papadopoulos, it seems that both Church and Oswald understood that discipline needed to be balanced with a respect for the troops' love of honour. Nevertheless, Church and the English could not fully identify with their charges, as is indicated in Church's letter to his mother (Lane-Poole 1890, p. 27):

Far different has been my task, and through the Almighty's assistance I have been enabled to reduce to obedience and military discipline men whom English, Russians, or French, could never in any way discipline or civilise. To you, mother, I do not boast; but I have now, thank God, divested those men of prejudices rooted by ages, and converted them from the most lawless of mankind, not only into good soldiers, but also into praiseworthy members or civilised society. These men, who once knew no law but their sword, are now the admiration of the inhabitants for their correct, quiet, and obedient conduct. My maxim has been to treat them with mildness and humanity, and by that means I have succeeded in gaining the love or these people beyond what can be imagined. The number of recruits that flock to me from all parts or Greece is really extraordinary...

Part of this attitude may have stemmed from an experience probably well known to Church. He mentioned how not only the Russians and French, but also the British, had difficulties "regularizing" these troops. This is not the first time the English attempted to form a Balkan unit. The earlier attempt on Malta in 1807 had dire consequences. There, the Greek, Albanian, and South Slav recruits were subject to the brutal discipline then common in the British Army. These auxiliaries, whose customary feeling for personal honour (Greek philotimo, Albanian besa and Slavic obraz) was not used to such treatment, did not long endure the abuse of English officers and mutinied in April 1807. The mutineers took over a strategic fortress overlooking the town of Malta and threatened to turn the fort's guns upon the town if their demands were not met. They demanded release from their service and that Russian or Septinsular ships return them to their homelands. While in 
control of the fortress, the rebel troops struck the Union Jack: and hoisted a makeshift Russian flag. The British, after an abortive assault on the fortress, blockaded the mutineers to starve them into submission. In time, most of the rebels surrendered and opened the gates, but a small contingent held out against the British and eventually blew up the fort's powder magazine, taking most of their own lives, along with those of a number of British troops. Summary executions of many of the mutineers occurred after the incident (Bunbury 1854, pp. 309-310, Fortesque 1912, pp. 30-32, Vlachogiannes 1965, pp. 1, 4) ${ }^{15}$.

Perhaps memories of this incident played a role in the eventual disbandment of the mainland units on the Ionian Islands. The British occupation of Corfu and the subsequent defeat of Napoleon greatly changed the situation of Greeks in both French and British service. In full possession of the Ionian Islands, the British began to disband the Greek formations. In July 1814, most of the Greeks in French service had their service and stipends ended, while in 1815 and 1816 the soldiers of the Greek Light Infantry Regiments lost their employment from service. In breaking up the Greek units, the British consolidated their control of the Ionian Islands by leaving defence solely in the hands of the protecting power, by removing an important vestige of previous regimes, and by placating the Porte, which saw the presence of these formations on the islands as a threat to the Ottoman Empire's security. Furthermore, the coming of peace in Europe obviated the maintaining of foreign troops in the British army (Pappas 1991, pp. 281-285.

This deactivation, however, proved to be a hardship for the mainland troops and their families, many of whom were still refugees. Those who could return to their homelands did so, while others found employment elsewhere. Some veterans took on service with the new Neapolitan formation, the Battaglione dei Cacciatori Macedoni between 1817 and 1820, while others found positions in the arnauţi guards of the Phanariote hospodars of Moldavia and Wallachia. Ali Pasha also employed a number of refugee veterans in his forces, some of whom had been his former enemies. However, the situation of most of the unemployed military exiles led many into revolutionary activities as members of the secret society for the liberation of Greek lands, the Philike Hetaireia, and subsequently as participants and leaders in the Greek War of Independence, 1821-1830 (Pappas 1991, pp. 288291).

\section{Conclusions}

What was the experience of British, French and Russian officers organizing, training and commanding Greco-Albanian troops on the Ionian Islands and their affect the development of the armed forces of Greece from 1821 on? There has been a divergence of views among scholars on the nature of this impact. Konstantinos Rados, in his pioneering study on the Souliotes and armatoloi on the Ionian Islands held that, "The corps of Greeks organized under the Russians, French and English were among the most important schools of the infantry force

\footnotetext{
${ }^{15}$ Gieben Griechen im Bulberturm. Soldatenerhebung auf Malta aus einer alten Leipziger Chronik. Wochenausgabe no. 14 (Vienna, 4 April 1936): 9-10.
} 
of the Revolution" (Rados 1916, pp. 31-33). In a similar vein, Giannes Vlachogiannes wrote that, "The Greek corps that served in the Ionian Republic were schools of military training for whole phalanxes of men, including Kolokotrones first, Niketaras, the Petimezas clan, as well as most of the Roumeliotes and Epirotes" (Makrygiannes 1947, p. 2). Commenting on these views held by Rados and Vlachogiannes, the American historian Dennis Skiotis wrote that, "... the argument is not convincing, since the European commanders tried to convert these Greeks into regular infantrymen, a hopeless task in view of the klephts' abhorrence for the "Frankish way of doing battle". Indeed when they did return to fight on the mainland it was not European squares and bayonet charges to which they resorted but the familiar and trusted tactics of the klephtopolemos" (Skiotis 1975, p. 319).

Nevertheless, I would have to qualify Skiotis' view. Under the Russians, at least, the veterans of the Legion of Light Riflemen did not receive training to fight in the "Frankish ways". As General Papadopoulos wrote in his manual for the Legion, "... it would be difficult and unbeneficial to have them drill in the order of European forces and for this they are designated as semi-regulars [aploutaktikoi] and will be called light hunters [elaphroi kinegoi]" (Rados 1916, p. 48). Under the French and Colonel Minot, the auxiliaries had to submit to the European tactical norms with little success. The French made a mistake by not having command positions held by Greek regular officers already in their service, such as those in the Chasseurs D'Orient ${ }^{16}$. Under the British and Colonel Church, there seems to be an attempt to modify their training and organization to take into account their penchant for skirmishing and klephtopolemos, although not to the extent that Papadopoulos advocated. Perhaps the British learned their lesson from the debacle on Malta. Even Church displayed some condescension in describing his charges as "the most lawless of mankind... who knew no law but their sword".

Indeed, most English and French observers, such as Pouqueville ${ }^{17}$, and Holland $^{18}$, usually had been critical of the auxiliaries, including their style of

\footnotetext{
${ }^{16}$ The only attempt to do this was when the French appointed Konstantinos Androutses as a Lieutenant Colonel of the regiment. Androutses was a member of a powerful Himariote clan, and had served in the Reggimento Real Macedone of Naples as a cadet from the age of ten. He was appointed a captain in the Neapolitan Bourbon Regiment twenty years later in 1797, and followed this with French service as a commander of a Neapolitan civil guard regiment in 1799, where he attained the rank of colonel-instructor. His position ended in 1799 by the restoration of King Ferdinand, after which he returned clandestinely to his homeland via the Ionian Islands, remaining in Himara as a representative of French interests until 1806. With the cession of the Ionian Islands to the French, he obtained the command of one battalion in the Regiment Albanaise. He was promoted to Lieutenant Colonel and was set to become virtual commander of the Regiment when he was captured in a small-scale raid on the Himara coast, one of the only offensive operations conducted by the Regiment. He languished in prison until 1812 and died under suspicious circumstances just before his negotiated release. Upon his death.

${ }^{17}$ Pouqueville displayed his prejudices describing some of his hosts in Himara: "I noticed that that our escorts watched the Himariotes' movements with care, and I divined that were amidst a den of bandits". (Pouqueville 1820, pp. 61-62).

${ }^{18}$ Holland describes the Greek Light Regiment in this manner: "The discipline of the men, when I saw them, was little advanced, and there seemed a singular inaptitude to acquire it; their appearance and movements were in all respects curiously rude and uncouth". (Holland 1815, p. 32).
} 
fighting and performance. For example, Thomas Hughes described members of the $1^{\text {st }}$ Greek Light Infantry Regiment he saw in Messina, Sicily in this manner (Hughes 1820, pp. 141-142):

... there was something of savage cunning and treacherous ferocity in their sparkling eye and red curling mustachios from which one naturally recoiled. It was found extremely difficult to subject these wild and lawless mountaineers, most of whom had exercised the profession of a robber, to the strict rules of European discipline, neither could they endure that kind of warfare which is in use amongst, civilized nations: accustomed to ambuscade and treachery, to occupy the passes and defiles of a mountainous country, and to fire upon an enemy from the protection of rocks, they could never be brought to stand and make a charge, or to remain steady under a fire of musketry; for at the first volley they generally fell flat upon their faces.

The one British traveller with an understanding of the character of the mainland irregulars was the Scot John Galt, who encountered troops of the $1^{\text {st }}$ Greek Light Infantry Regiment, compared them to the Scottish highlanders:

It is called the Greek light infantry. The dress is the Albanian, except in one company, which, being entirely composed of Mainotes, is clothed in what may be called the Spartan uniform. I dined at the officers' mess on the occasion of General Oswald's first visit to them, and was not a little amused - We had several Albanian songs-odes I should call them, as were [in] the language of the · Greeks. The style of the airs resembled the Highland pibrochs. Indeed, in their manners these mountaineers are not unlike our highland countrymen. They have the same skinless sense of honour, and between them and their followers the same kind of attachment, and in many cases the same relationship exists, which constituted the peculiar cement of the Scotish [sic] clans. One of the. Greek officers sung an old set of the blue hells of Scotland, not the least extraordinary incident in the entertainment I think you must allow.

In spite of this fascinating metaphor, Galt felt that the British government should not recruit these men without the permission of the Ottoman. He seemed not to have any understanding of the status of the mainland troops as refugees.

In contrast, most Russian observers, including Benkendorf ${ }^{19}$, Bronevskii, ${ }^{20}$ and Svi'nin ${ }^{21}$, had favourable impressions of the mainland troops, praising their

\footnotetext{
${ }^{19}$ Benkendorf said this about them, "For 17 years, the unbelievable tenacity and ferocity of these brave mountaineers protected them against all attempts of Ali Pasha. .... I was entrusted with the command of the Souliote Legion; I cannot say that I organized it, because it seemed to me that 17 years of a deadly war was its military organization".

${ }^{20}$ Vladimir Bronevskii recounted a remarkable incident which occurred during the Turkish siege of Tenedos in June. It was then that an envoy from the Turkish camp, met his own brother by chance serving in the Legion. This envoy, under a flag of truce, attempted to sow discord among the troops and his own brother forcibly expelled him. Before evicting his brother, the legionnaire reportedly said (Bronevskii 1837, pp. 122-124):

... I serve the Orthodox ruler, the only hope with which it is possible to resurrect humiliated Greece; you serve our tyrant, the enemy of God and the Church; I defend the fatherland, you oppress it. Now we are enemies; it could happen that your hand takes my life or I bring about your death.
} 
loyalty and skill at arms. Take for example, Pavel Panafidin's description of legionnaires' fighting methods (Panafidin 1916, pp. 18-19):

They are excellent jaegers. When one of them shoots his long musket from behind a rock and does not have time to reload his musket; he pulls out a pistol, fires it, then another, and at the same time, his sabre is already in his other hand protecting his head. He transfers the sabre to his right hand, ready to enter hand-to-hand combat; but in the meantime the musket and two pistols, which are on fuses, are ready to be loaded again. Having repulsed the enemy, he again loads his weapons, again gives off three shots and draws his sabre, which hangs [from a scabbard] at a near horizontal position.

Three factors may account for this difference in attitude toward these troops. First, the legionnaires may have performed better under the Russians because together they fought against a familiar foe, the Ottoman Empire. Second, the bond of their common Orthodox faith may have made for good relations between the Russians and their auxiliaries. Finally, the use of irregular forces, such as the Cossacks, may have made the Russian military more tolerant of forms of combat and military customs different from the European practice.

These Russian memoirists mirrored the respect and confidence that Emmanouel Papadopoulos had for his legionaires. He commanded the mainland refugee warriors after the brief stint of Alexander Benkendorf and I consider him one of the founders of the Modern Greek military. He melded the disparate group of Souliotes, Himarriotes, Maniates, klephtes, armatoloi, kapoi, and others, scattered over several islands into a 3000-man force. He composed a constitution and guide for this unit in the forms of it convention and manual. In these documents, he has an appreciation for the mainlanders' qualities as soldiers and well as a toleration of their shortcomings, using careful training and discipline to bring out their assets and to minimize their debits. The French and the British only followed what Papadopoulos had pioneered in the organization and deployment of the precursor of their later Regiment Albanaise and the Greek Light Infantry Regiment. Whether they succeeded failed depended on how far they strayed from Papadopoulos' balanced approach to training, organization, and command. Subsequently, western and westernizing officers in the Greek revolutionary forces and the army of the early Modern Greek state would have to deal with the same problems in reconciling "irregular" martial traditions with European "regular" military norms (Pappas 2018, pp. 179-183).

A young scholar would do well to research and write a biography and study of Emmanouel Papadopoulos. His career, from his youth and training in Russia to his untimely death at the battle of Shumla in Moldavia in 1810 would go far to in

\footnotetext{
${ }^{21}$ Pavel Svinin described the legionnaires quartered on his ship, including their dancing, songs and costumes. He also gave an account of the Souliote wars to tell the troops' origin. Commenting on their qualities as soldiers, Svinin (1815, pp. 6-10) wrote:

Every activity, every glance expresses the warlike spirit of this people, reminiscent of the wars of Alexander the Great, of Pyrrhus, and of Skenderbeg, preserving after the fall of the [Byzantine?] empire an independent character and a thirst for armed exploits: they become animated by the firing and the clashing of weapons.
} 
understanding the origins of the modern Greek military. A fitting epitaph was composed by Metropolitan Ignatios, Papacomrade in arms.

\section{References}

Arsh GL (1972) Zapiska o nyneshicm sostoianii grckov (1811 g.) I. Kapodistrii. (Note on the current state of the grchkov (1811) I. Kapodistrias). Slaviano-Balkanskie issledovaniia istoriografiia i istochnikovedenie. Volume 3. Moscow: Nauka.

Arsh GL (1976) I. Kapodistriia i grecheskoe natsional'no- osvoboditel'noe dvizhenie, 1809-1822 gg. (I. Kapodistria and the Greek National Liberation Movement, 18091822). Moscow: Nauka.

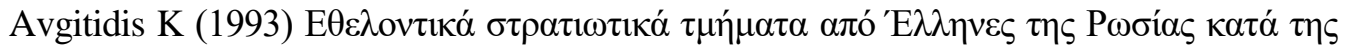

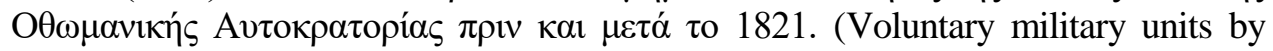
Greeks of Russia against the Ottoman Empire before and after 1821). Athens.

Boppe A (1901) Le regiment Albanaise. (The Albanian regiment). Carnet de la Sabretache 9(99): 161-162.

Boppe A (1914) Le regiment Albanaise (1807-1814). (The Albanian regiment (18071814)). Appendix in L'Albanie et Napoleon 1807-1814. Paris: Berger-Levrault.

Bronevskii V (1837) Zapiski morskago ofitsera, v prodolzhenii kampanii na Sredizemnom more pod nachalstvom. Admirala D. N. Seniavin ot 1805 do 1810 god. (Notes of a naval officer, in the continuation of the campaign in the Mediterranean under command. Admiral D. N. Senyavin from 1805 to 1810). Volume 3. St. Petersburg.

Bunbury H (1854) Narrative of some passages in the great war with France from 1799 to 1810. London: Richard Bentley.

Beskrovnyi LG (1958) Russkaia armiia i flot $v$ XVIII. (Russian army and navy in the XVIII). Moscow: Nauka.

Casanova J (1924) Memoires. Volume 1. Paris: Editions de la Sirène.

Convention of the Epeirotosouliotes and Peloponnesians with General D'Anrep (1805) Historical and ethnological society of Greece, collection of documents (1686-1831). No. 16966.

Dakin D (1955) British and American philhellenes during the war of Greek independence.

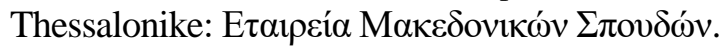

"Emmanuil Grigor'evich Papandopulo" (1846) Voennyi entsiklopedicheskii leksikon. (Military encyclopedic lexicon). Volume 10. St. Petersburg.

Fortesque JW (1912) History of the British army. Volume 5. London.

Grasset de Saint-Sauveur A (1800) Voyage historique, litteraire et pittoresque dans les isles et les possessions ci-devant venitiennes du Levant. (Historical, literary and picturesque journey in the formerly Venetian islands and possessions of the Levant). Volume 2. Paris.

Holland H (1815) Travels in the Ionian Islands, Albania, Thessaly, Macedonia, etc. during the years 1812 and 1813. London.

Hughes TS (1820) Travels in Sicily, Greece and Albania. Volume 1. London: J Mawman.

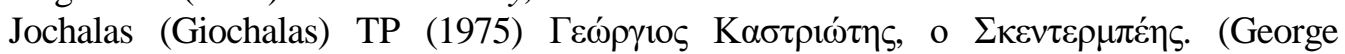
Kastriotis, the Skenterbeis). Thessalonike.

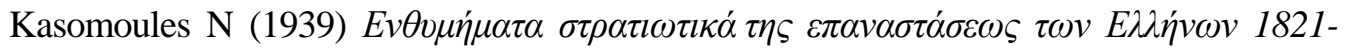
1833. (Military memoirs of the Greek revolution 1821-1833). G. Vlachogiannes (ed.), volume 1. Athens.

Klochakev T (1902) "Emmanuil Grigor'evich Papandopulo". Russkii Biograficheskii Slovar 13. St. Petersburg. 


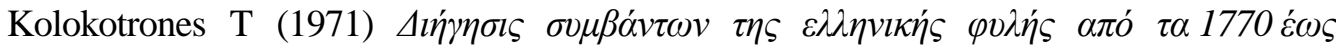
$\tau \alpha$ 1836. (Narration of events of the Greek race from 1770 to 1836). Athens: Papyros.

Korguev N (1897) Korpus chuzhestrannykh edinovertsev. (Corps of outlander aliens). Morskoi Sbornik (7): 155-164.

Korguev N (1913) Korpus Chuzhestrannykh Edinovertsev. (Corps of outlander aliens). Voiennaia Entsiklopeniia 8: 197-198.

Lane-Poole S (1890) Sir Richard Church, C.B., G.C.H. commander-in Chit of the Greeks in the war of independence. London: Longman's.

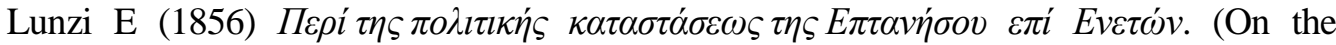
political situation of the Ionian Islands during the Venetians). Athens: Tó $\pi$ ors X.

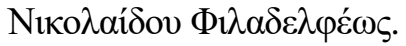

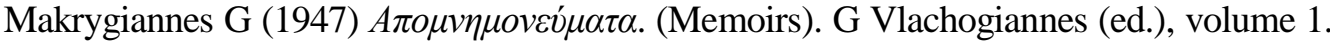
Athens.

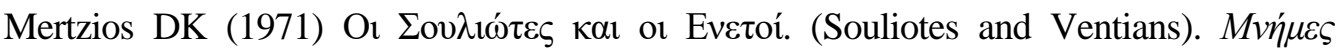
Soviiov 1: 310-313.

Panafidin PI (1916) Pis'ma morskago ofitsera. (Naval office letters). Morskoi Sbornik 343(4): 18-19.

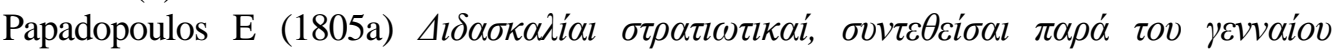

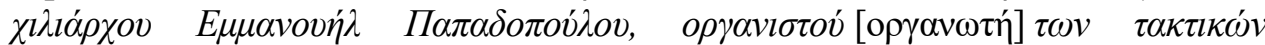

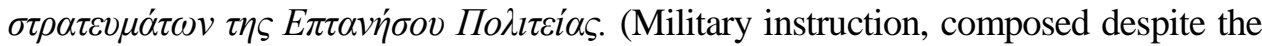
brave thousand Emmanuel Papadopoulou, organizer of the regular troops of the Ionian State). Corfu.

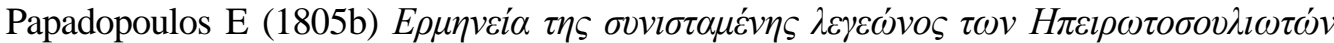

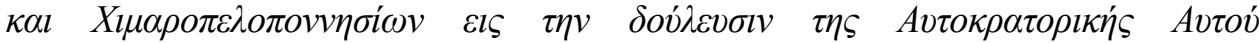

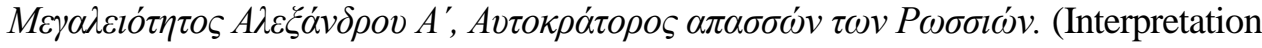
of the constituent legion of the people of Epirus and the Himalayas in the work of His Eminence Alexander I, Emperor of the Russians). Corfu.

Pappas N (1981) Balkan foreign legions in eighteenth century Italy: the reggimento real Macedone and its successors. In I Banac, J Ackerman, R Szporluk (eds.), Nation and Ideology: Essays in Honor of Wayne S. Vucinich, 35-59. East European Monographs and Columbia University Press.

Pappas N (1991) Greeks in Russian military service in the late eighteenth and early nineteenth centuries. Thessaloniki: Institute for Balkan Studies.

Pappas N (2018) Brigands and brigadiers: the problem of banditry and the military in nineteenth century Greece. Athens Journal of History 4(3): 179-183.

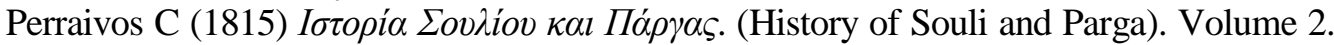
Venice.

Pouqueville FCHL (1820) Voyage dans la Grèce. (Travel to Greece). Volume 1. Paris.

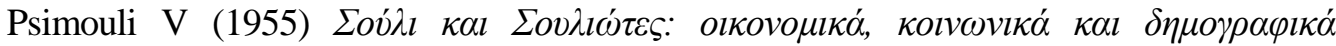
$\delta \varepsilon \delta o \mu \varepsilon \dot{\varepsilon} \alpha$. (Souli and Souliotes: economic, social and demographic data). Doctoral Dissertation. Athens: Ionian University.

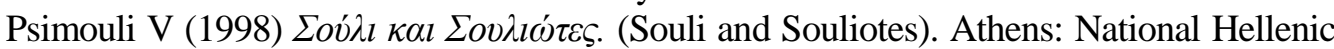
Research Foundation.

Psimouli V (2005) $\Sigma o v ́ \lambda \iota ~ \kappa \alpha l ~ \Sigma o v \lambda \imath \omega ́ \tau \varepsilon \varsigma$. (Souli and Souliotes). $2^{\text {nd }}$ Edition. Athens: Estia.

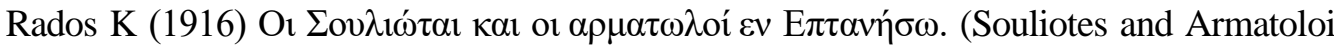
in the Ionian Islands). Epeteris Philologikou Syllogou Parnassou. Volume 12.

Rodocanachi E (1899) Bonaparte et les iles Ioniennes. (Bonaparte and the Ionian Islands). Paris.

Rothenberg G (1966) The military border of Croatia, 1740-1881. Chicago: University of Chicago Press. 
Rothenberg G (1978) The art of warfare in the age of Napoleon. Bloomington: Indiana University Press.

Skiotis D (1975) Greek mountain warriors and the Greek revolution. In VJ Perry, ME Yapp (eds.), War. Techology and Society in the Middle East. London.

St. Claire W (1972) That Greece might still be free: the philhellenes in the war of independence. Oxford: Oxford University Press.

Stanislavskaja AM (1976) Rossija i Grecija v konce XVlII-nalale XIX veka. Politika Rossii $v$ loniieskoj Respublike 1798-1807gg. (Russia and Greece during the late XVIII ${ }^{\text {th }}$ and early XIX ${ }^{\text {th }}$ centuries. Russia's policy in the Ionian Republic between 1798-1807). Moscow: Nauka.

Svinin P (1815) Vospominanie na flote. (Remembrance in the navy). St. Petersburg.

Tarle E (1959) Admiral Ushakov na Sredizemnomore (1798-1800). (Admiral Ushakov in the Mediterranean (1798-1800)). In Sochinenie 10. Moscow.

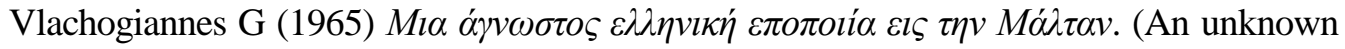

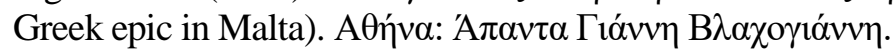

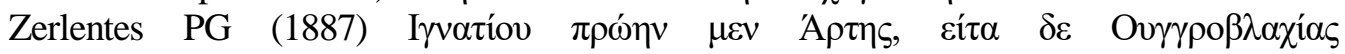

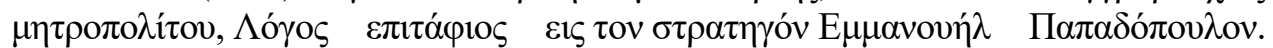
(Ignatius, formerly Artis, or metropolitan of Hungary, Speech epitaph to General Emmanuel Papadopoulos). Parnassos 11: 201-207.

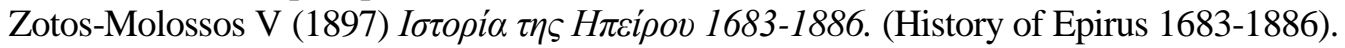
Athens: Vasileios Zotos-Molossos Archive, General State Archives, folio K97. 
